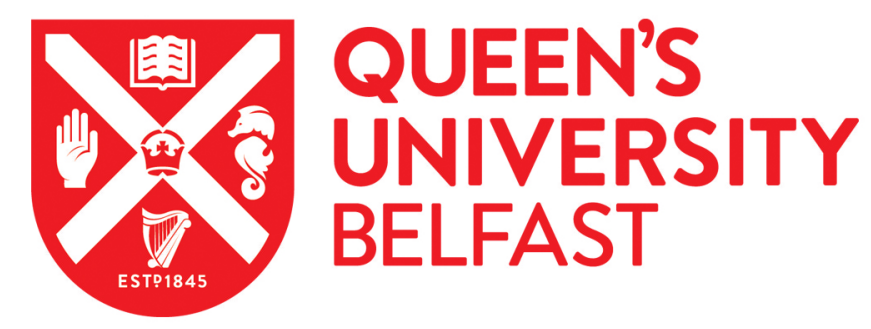

\title{
Crown, communication and the colonial post: stamps, the monarchy and the British Empire
}

Jeffery, K. (2006). Crown, communication and the colonial post: stamps, the monarchy and the British Empire. The Journal of Imperial \& Commonwealth History, 34(1)(1), 45-70. https://doi.org/10.1080/03086530500411290

Published in:

The Journal of Imperial \& Commonwealth History

Document Version:

Publisher's PDF, also known as Version of record

Queen's University Belfast - Research Portal:

Link to publication record in Queen's University Belfast Research Portal

\footnotetext{
General rights

Copyright for the publications made accessible via the Queen's University Belfast Research Portal is retained by the author(s) and / or other copyright owners and it is a condition of accessing these publications that users recognise and abide by the legal requirements associated with these rights.

Take down policy

The Research Portal is Queen's institutional repository that provides access to Queen's research output. Every effort has been made to ensure that content in the Research Portal does not infringe any person's rights, or applicable UK laws. If you discover content in the Research Portal that you believe breaches copyright or violates any law, please contact openaccess@qub.ac.uk.
} 


\section{Crown, Communication and the Colonial Post: Stamps, the Monarchy and the British Empire}

\section{Keith Jeffery}

This article investigates some of the possibilities for imperial history of using philatelic evidence. It explores the ways in which the British empire as a working world system was underpinned by the Imperial Penny Postage and the production and use of postage stamps bearing the images of successive British monarchs and other British imperial iconography. With particular emphasis on the reign of George V, who took an especially close interest in philatelic matters, it charts and discusses some of the ways in which British, dominion, Indian and colonial postage stamp issues (including their commissioning, design and public reception) reflected political and aesthetic judgments at home and overseas, and expressed sometimes unexpected notions of appropriate imperial, dominion and colonial imagery. It provides some cultural evidence supporting the contention that the apogee of the British imperial system may have occurred sometime in the middle years of the twentieth century.

Eric Hobsbawm has been credited with asserting that 'there is history and there is stamp-collecting, and it is important not to confuse the two', a statement which always raises a laugh in a seminar or lecture, neatly, it seems, distinguishing analytical historians (us) from mere antiquarian chroniclers (them); the reflective, ruminant sheep, perhaps, from the grim, Gradgrind goats. Yet every serious historian collects and systemises, perhaps no longer 'facts', but at least morsels of information, as keenly and assiduously as any philatelist might gather and arrange postal treasures. And goats can be giddy too, making connexions that the steady sheep may miss. So it is that we may essay some reflections on the modern British empire, touching on aspects of the visual 'construction' of that world system, using philatelic evidence as a primary focus.

Correspondence to: Professor Keith Jeffery, History, Queen's University, Belfast BT7 1NN. Email: k.jeffery@qub.ac.uk 
Postage stamps have a significant representational quality for the state which issues them. In March 1926 the poet W. B. Yeats told the Irish Senate that postage stamps and coins could be described as 'silent ambassadors of national taste.' Writing in the magazine Country Life for the centenary of the postage stamp, the art historian Nikolaus Pevsner described a stamp as 'a piece of national advertising more widely circulated than any other.' ${ }^{2}$ Yeats and Pevsner could be expected particularly to stress the aesthetic aspects of these public manifestations of nationality. But stamps are much more than that. They are also emblematic of political as well as cultural matters. They are intensively used and, as Pevsner noted, very widely distributed. There is a formal design process in which the wider public often takes a keen interest. Thus these apparently trivial and ephemeral artefacts can touch the everyday lives (and reflect the attitudes) of both governments and ordinary citizens more readily than grand political rhetoric or state ceremonial. Within the British empire, moreover, the choice of images for stamps can indicate underlying assumptions about the role and meaning of empire. ${ }^{3}$

The semiotics of stamp design, as David Scott has usefully demonstrated, can be a rewarding and revealing study. By distinguishing between the indexical, the iconic and the symbolic functions, he aims to clarify the way stamp messages are structured and the ideological implications they carry. Scott argues that although a stamp 'functions primarily as an indexical sign (pointing to the country of origin), as an object it encompasses iconic and symbolic elements', the former including pictures or images, the latter with letters and numbers. ${ }^{4}$ The iconic elements, moreover, comprise the least essential (and therefore arguably the most interesting) parts of what actually needs to be provided on a letter or parcel. 'There is no reason', writes Humphry McQueen in an Australian study, 'why stamps should carry any imagery or decoration whatsoever.' Unlike the 'adhesive receipts' increasingly being generated by machines in modern post offices, 'postage stamps were not merely utilitarian. The inclusion of images has meant that the postage stamp was supposed to do more than prove that the charges for delivery have been met. ${ }^{5}$

Making a comparison with the study of coins, Donald M. Reid has asserted the value of philatelic evidence for the historian. Numismatics, he notes, is recognised as a scholarly discipline; philately is not. ${ }^{6}$ While chairs of historical numismatics are not uncommon, chairs of historical philately are rather less so. Reid contends that the establishment of an organised, efficient postal service, complete with stamps, on the model of the British penny post introduced in 1840, is an important indicator (and facilitator) of modernisation. But the great achievement of establishing a reliable national and international postal service rarely gets much of a mention in general histories of the nineteenth century. Reid observes that Hobsbawm makes no mention whatsoever of postal services or stamps in the chapter entitled 'The World Unified' in his Age of Capital, ${ }^{7}$ while the development and impact of the electric telegraph is emphasised. ${ }^{8}$ Yet the postal services were more ubiquitous, democratic and dramatically more heavily-used than the telegraph. In 1875, for example, 21 million 
telegrams were sent in the United Kingdom as opposed to over 1,000 million letters and 366 million other postal items. ${ }^{9}$ Thirty years on, the relative proportions had not very greatly changed. In 1906-07 more parcels were sent in the United Kingdom than telegrams (104 million to 80 million), and nearly 60 times the number of other postal items. ${ }^{10}$ Along with the telegraph, Hobsbawm also dwells on the steamship and the railway, which both undoubtedly underpinned what Reid calls the 'postal revolution'. Hobsbawm, it seems, is more of a train-spotter than a stamp collector.

Historians of the British empire have been equally diffident about mentioning (let alone discussing) postal matters. In a chapter on 'finance, trade and communications' between 1870 and 1895 in the Cambridge History of the British Empire, E. A. Benians merely noted that 'a proposal for an Imperial Penny Post' was discussed at the 1887 colonial conference. G. S. Graham, covering the same topic from 1895 to 1914, ignored the imperial penny post altogether, but when discussing submarine cables suggestively wrote that 'what the penny postage did for the United Kingdom after 1840, sixpence-a-word cables might accomplish for the whole Empire." ${ }^{11}$ Forty years on, E. H. H. Green in The Oxford History had nothing to add. The colonial and imperial conferences which met between 1887 and 1914 provided 'an increasingly important forum for policy discussions on matters ranging from Imperial defence and trade to the laying of the "all red route" of transoceanic cables and the Imperial penny post.' ${ }^{12}$ Ronald Hyam has suggested that 'the cable, it could be argued, was more important than the steamship or the railway because it carried information overseas, ${ }^{13}$ as if ships and trains themselves did not carry mailbags full of all kinds of information. Bernard Porter mentions postal matters only in the context of India. After ten lines describing the impressive growth of the Indian railway system, he adds that 'progress in other fields was not so dramatic, but irrigation works, the construction of roads, the extension of telegraph and postal services, the provision of sanitation and lighting, and other public works were pushed ahead steadily. ${ }^{14}$ In another general survey of imperial history, T. O. Lloyd makes no mention whatsoever of postal services, apart from a passing allusion to the 1898 Canadian stamp showing a map of the empire. ${ }^{15}$ Lloyd, moreover, although based in a Canadian university, clearly has no idea of why specifically the stamp was issued. Considering its subject-matter, one might have expected David Cannadine's recent exploration of 'how the British saw their Empire' to pay some attention to postage stamps. Alas not, bar the sweeping generalisation that 'throughout the empire, coins and stamps bore the image of the queen-empress or the king-emperor. ${ }^{16}$ As we shall see, this was true only up to a point. The royal image was by no means consistently used 'throughout the empire', and when it was employed, it was with revealing variations.

Only James Morris (are we surprised?) devotes more than a line or two to the topic. In chapter three of Pax Britannica, 'Life-lines: the shipping routes, mails and cables that bound the British possessions together', Morris demonstrates in two pages a number of avenues which the cultural historian of empire could profitably pursue. Mention of 'Mr Stanley Gibbons's stamp catalogue' (already in its thirty-second year by the time of Queen Victoria's diamond jubilee) suggests that the actual study 

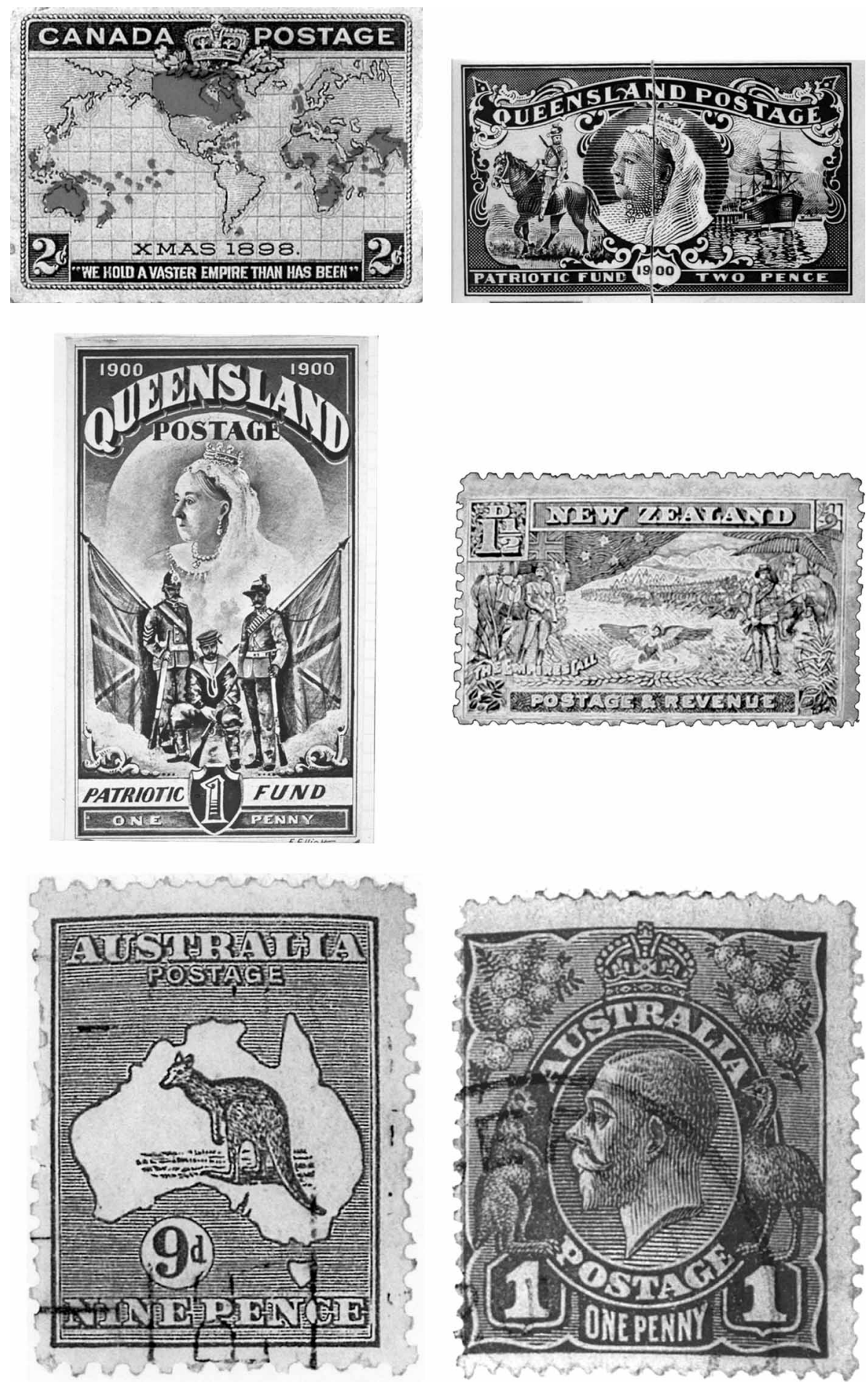

Figures 1-6 
of stamp-collecting (which is sometimes cited by old colonial hands as having stimulated their interest in the empire ${ }^{17}$ ) might be revealing for the world-view of British young people (and perhaps older ones too) during the heyday of empire. Morris observes that by the 1890s 'well over 22 million letters and postcards went from Britain to her possessions in a single year. ${ }^{18}$ But what does this figure mean? Tracking the volume of colonial post by destination, direction and seasonality might tell us much about the British at home and in the empire, and their interchanges and relationships. The growing volume of postal activity within British imperial possessions can also be used as an indicator of expanding and changing economic activity, as well as increasing levels of literacy. Morris also mentions some of the actual postal workers, British and indigenous, whose history could well be explored, not least because post office workers often (after state railways) constituted the largest single group of government employees. ${ }^{19}$ In many colonies, moreover, the establishment of post offices throughout the territory inevitably marked an extension of government bureaucracy and control, a process which is likely to have been extremely well documented. $^{20}$

\section{II}

Central to any exploration of British and British imperial stamps is the image of the imperial monarch. The uniquely distinguishing feature of British stamps is that they carry no formal indication of the country of issue other than the monarch's head, a legacy of the United Kingdom pioneering the development and use of postage stamps. ${ }^{21}$ The first British stamps - the famous 'Penny Black' and 'Twopenny Blue' of 1840 - showed Queen Victoria's head with the words 'postage' and 'one penny' to indicate function and value respectively. From the start there was a semiotic ambiguity, with the iconic image of the monarch also conveying the practical, indexical information that the stamp was British. There is, here, a happy conflation of what Walter Bagehot famously identified as 'dignified' and 'efficient' parts of the British constitution. $^{22}$ Echoing what Bagehot called a 'disguised republic' - a representative system strengthened and protected by a 'theatrical' show of royal ritual - there is a disguised element of modernity, a grafting of ancient (or at least medieval) symbolism and pageantry onto an extremely up-to-date and radical development. It is similar to the ways in which the 'invention of tradition' can sometimes mask (and permit) quite significant changes in government and administration. ${ }^{23}$

The 'postal revolution' of 1840 brought the introduction of a uniform and cheap postal rate (of one penny for half an ounce) for the entire country. The originator of the reform, Rowland Hill, originally wanted it to operate for overseas as well as domestic mail. There was scarcely any other measure, he maintained, that 'would tend so effectually to remove the obstacles to emigration, and to maintain the sympathy between the colonies and the mother country. ${ }^{24}$ And although this development was not to come for another 50 years, the pre-paid envelopes, designed by William Mulready, which were issued simultaneously with Hill's postage stamps, suggested a wider, global reach for the reformed postal service. Mulready's design was 
unambiguously imperial. In the centre Britannia with outstretched arms sends winged messengers to the four corners of the earth. On the left are East Indians, Arabs and Chinese; on the right Amerindians, Pilgrim Fathers and Afro-Caribbeans. ${ }^{25}$ Mulready's 'covers' were much derided, on practical as well as aesthetic grounds, and were rapidly withdrawn. Thereafter the adhesive stamp held sway. From the beginning there were separate rates for colonial and foreign letters. Although some rates for destinations in continental Europe were lower than charges for letters to, say, Canada, in postal terms, beyond Europe, the formal British empire was consistently more privileged than other clearly less fortunate parts of the world.

From 1840 until Queen Victoria's death in 1901, the design of British stamps remained essentially unchanged. The same queen's head as appeared on the penny black (which was based on a medal engraved by William Wyon in 1838) was used for the rest of her reign. ${ }^{26}$ This youthful, Dorian Gray-like image contrasted with the changing likeness on Victoria's coins, ageing markedly in the $1890 \mathrm{~s}^{27}$ Only the framing and colours, along with additional values, varied over the years. ${ }^{28}$ While on her head the queen wore a regal tiara, an 'imperial crown' watermark was used from 1880. Identifiable only on the reverse of the stamp, this reflected Queen Victoria's much more visible change of status to 'Empress of India' from 1877. On the stamps of her three male successors, Edward VII, George V and George VI, the practice changed. Embodying an intensification of imperial imagery in their stamps, the monarch's head was consistently surmounted or associated with the imperial crown. ${ }^{29}$ In 1952 the practice changed again. Apart from Queen Elizabeth II's coronation stamps of 1953, on which both the imperial and state crowns appear, the crown disappeared almost entirely from British stamps. Between 1952 and 1966 Queen Elizabeth, like her great-grandmother, was invariably depicted wearing a tiara, but since then some commemorative issues have used a bareheaded version of the queen's profile. The removal of imperial and royal iconography from British stamps perhaps stems from a conscious demystification of monarchy, but it also undoubtedly reflects its increasingly diminished status over the second half of the twentieth century and beyond.

Queen Victoria eventually graced the stamps of nearly every British imperial possession, including 1867-75 issues for Heligoland (printed in Berlin) and an 1878-80 issue for Transvaal. But she never appeared on the stamps of British Guiana (issued from 1850) or the Cape of Good Hope (from 1853). There was, moreover, no consistency at all about the use of the monarch's image. While she was displayed on all the stamps of India and the Australian states of Queensland and Victoria (naturally enough, one supposes), New South Wales began with a series of stamps showing views of Sydney, Newfoundland depicted heraldic flowers of the United Kingdom, Western Australia's first stamps were graced with a black swan, Barbados had Britannia, and the Colony of Canada commenced in 1851 with $3 d$., $6 d$. and $12 d$. stamps showing a beaver, Prince Albert and Queen Victoria respectively. Although the highest value was reserved for the monarch, the stamp most people would have used was the beaver, which was, however, surmounted with a royal 'VR' cipher. Towards the end of the nineteenth century, some territories began issuing 
pictorial stamps, clearly intended both to provide publicity and earn revenue from stamp-collectors. In 1897 a Newfoundland series showed pictures of logging, fishing and mining. A New Zealand series the following year celebrated the natural beauties of the land, and in 1899 Tasmania followed suite. Issues such as these remind us that one function of postage stamps was to establish and advertise the colonial presence on the wider imperial and international stage.

The choices made for stamp designs by local British colonial administrators might be thought to illuminate contemporary colonial self-perceptions. But a simplistic analysis which on the one hand equates a slavish reproduction of royal or British iconography with colonial loyalty and, on the other, local images with separatism will not do. Two colonies which eschewed the monarch's image, Western Australia and Cape Colony were notable in the mid-nineteenth century for having failed to demand (and receive) responsible government. ${ }^{30}$ Western Australia, in fact, had postage stamps for nearly 50 years before using any showing Victoria's head, which, ironically, were only issued the year after the old queen died. From 1854 to 1903 the colony stayed exclusively with a swan emblem on its stamps, displaying a greater singularity than any other Australian colony, an independence of spirit underpinned by geographical remoteness and further demonstrated by it being the last colony to accede to Australian federation. ${ }^{31}$

The Canadian 'map' stamp of 1898 (see Figure 1) had a special significance, as it marked the inauguration of the imperial penny post. Two men are credited with the success of the campaign for this development: John Henniker Heaton and William Mulock. ${ }^{32}$ Heaton was a British MP with property interests in Australia who was first elected (as a Conservative) in 1885. The following year he started a campaign to reduce the cost of postage between Britain and the empire. ${ }^{33}$ There were both practical and emotional arguments in favour of the measure. The former were based on the sound (and as it turned out accurate) economic assumption that a reduction in price would lead to an increase in demand. Heaton, however, was more inclined to stress the latter. 'Our strongest argument ..., he asserted, 'though it could hardly be stated in pounds, shillings and pence, was the sun-browned emigrant, with his dependents here and across the ocean. ${ }^{34}$ Practically personifying Heaton's vision (though we do not know how 'sun-browned' he might have been) was William Mulock, who became postmaster general of Canada in 1896. The following year, much to the irritation of the British authorities, he unilaterally reduced the letter rate from Canada to all other parts of the empire. The British Post Office was not at all keen, believing that any general reduction in rates would be uneconomic, and the postmaster general, the Duke of Devonshire, clearly took umbrage at having his hand forced by a colonial colleague. ${ }^{35}$ Mulock argued that particular resentment was caused in Canada through postage rates to the United States being lower than those to the United Kingdom. What the Canadian government desired, he asserted, was 'to afford the amplest and freest facilities for intercourse between Canada and the rest of the British possessions. ${ }^{36}$

Mulock got his way. London consented to convene an imperial conference on postage rates' in July 1898 and, with the support of the colonial secretary, Joseph Chamberlain, an imperial penny postage was agreed between representatives of 
Britain, Canada, Newfoundland, Cape Colony, Natal and the Crown Colonies. These territories launched the scheme on Christmas Day 1898, a notably swift implementation of a decision. Australia and New Zealand did not fully participate until $1911 .^{37}$ Pressure for the introduction of an imperial penny post clearly came from much the same sorts of people as were supporting notions of imperial federation. As it happened, the imperial penny post was the only part of the imperial federation vision which ever had any practical effect. ${ }^{38}$ The Times particularly welcomed a measure which brought affordable postage to the 'masses'. 'By bringing the postage of the Empire within the reach of the poorest', it declared, Henniker Heaton had 'rendered vocal innumerable chords which have long been dumb, and acclaimed the unity of the Empire by the responsive chorus of myriads of gladdened hearts. ${ }^{39}$

As Henniker Heaton had predicted, moreover, the new postage rate also had a striking impact on the volume of imperial mail, with that of letters and postcards more than doubling between 1897-98 and 1903-04. ${ }^{40}$ In order to assess the significance of this traffic, it is also worth re-emphasising the disparity in cost between sending a letter and a telegram. From 1906, when it cost a penny to send a half-ounce letter from Britain to anywhere in the empire, ${ }^{41}$ telegram rates per word varied from one shilling (Canada), two shillings (India) to three shillings (New Zealand). ${ }^{42}$ Telegrams were only for governments, commercial concerns, the very rich and the desperate. In ordinary circumstances, the overwhelming preponderance of imperial communications depended on the postal services.

William Mulock also proposed that there should be a common empire stamp to accompany the penny post, ${ }^{43}$ but in this instance he was unsuccessful. He pressed ahead with a Canadian stamp, however, which he designed himself, aiming both to 'perpetuate interest in the event' and to emphasise 'the vast extent of the British Empire'. The stamp had a value of two cents (equivalent to one penny), and depicts a map of the world with the empire marked in red. Above the map is the imperial crown, and below it the words 'We hold a vaster Empire than has been', a quotation from the Welsh poet Sir Lewis Morris's 1897 Diamond Jubilee Ode, 'A Song of Empire. ${ }^{44}$ The arrangement of the world map shows Canada in the centre, and, with the distorting effect of Mercator's projection (which is always a favourite in Canada), ${ }^{45}$ the apparent size of the dominion is hugely amplified. It is perhaps worth remarking that with this stamp and one in 1932 (for the Ottawa imperial economic conference), Canada is the only part of the empire which issued any stamps explicitly celebrating and marking the empire with a suitably-marked world map. It is well established that Canada from the late nineteenth century increasingly asserted its autonomy from the 'mother country', ${ }^{46}$ but it is equally plain that the trends were not wholly or exclusively in one direction. There were, to be sure, ambiguities in Canada's imperialism, and, as Carl Berger has argued (for English Canadians at least), 'imperialism was one form of Canadian nationalism, ${ }^{47}$ a notion well illustrated by the design of the 1898 stamp, which placed Canada at the centre of the empire. Yet 30 years later, the Ottawa conference stamp put Britannia at the centre: 'shurely', as Private Eye might say, 'shome mishtake'? 

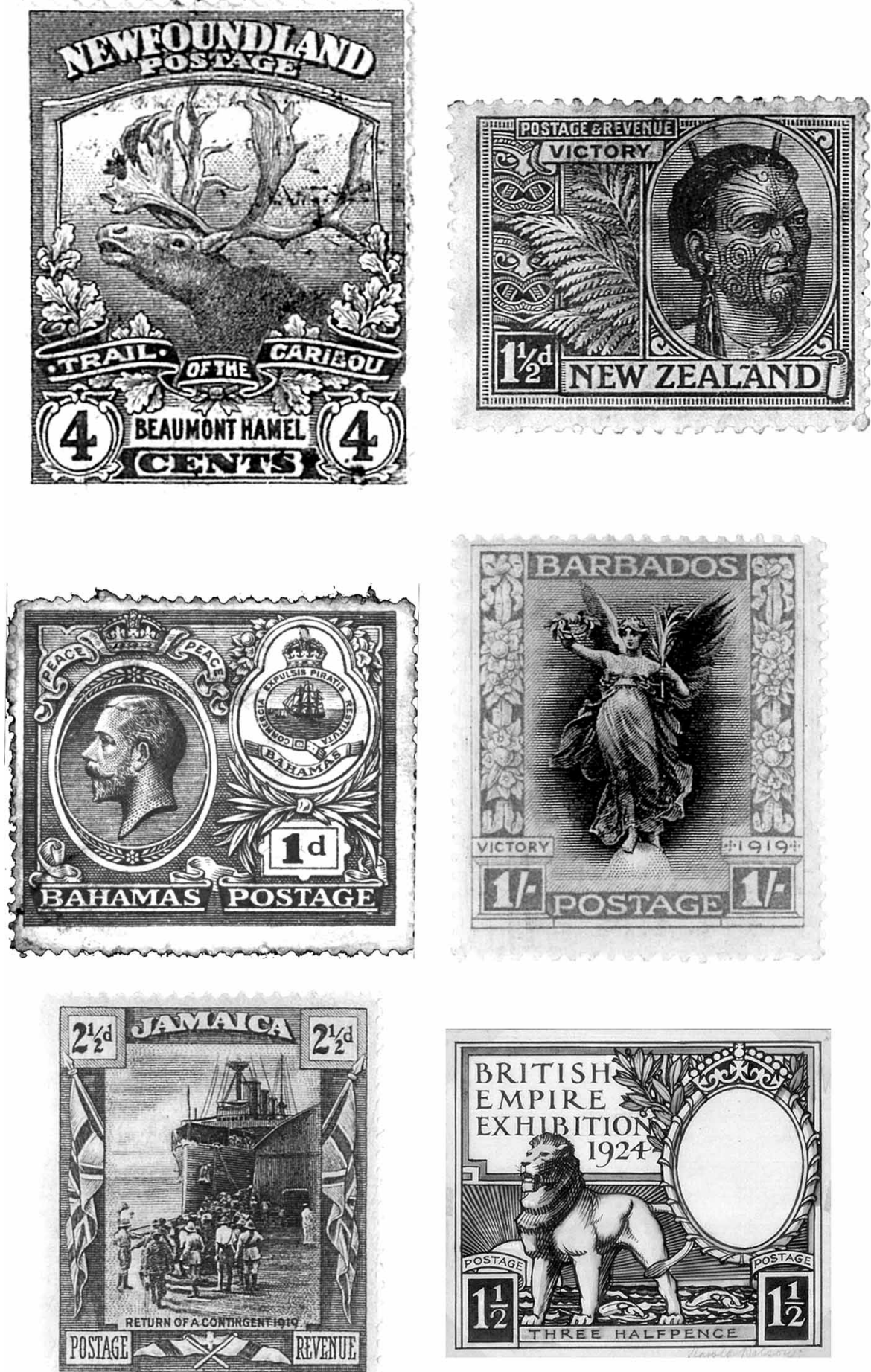

Figures 7-12 
Hot on the heels of the imperial penny post, the South African War of 1899-1902 gave three territories the chance philatelically to celebrate imperial service. The Boer War marked the first significant colonial contributions to a British imperial war effort, with over 28,000 personnel from Canada, Australia and New Zealand participating. ${ }^{48}$ In May 1900 the Australian colony of Victoria issued two stamps primarily intended as a money-raising device. The stamps were sold for one and two shillings, but paid postage of one and two pence, the difference going to a 'Boer War Patriotic Fund'. The images chosen were entirely military: the one penny shows a Victoria Cross, the two penny has three soldiers, two on horseback. Evidence has survived of the design process for a similar 'Patriotic Fund' issue in Queensland. ${ }^{49}$ Fred Elliott of the Queensland Post and Telegraphic Department prepared a number of possible designs, including a troopship leaving Brisbane, a South African battle scene, and a composite essay, combining troopship, horseman and the Queen's head (see Figure 2). The close proximity of the horse's rear end and Victoria's nose, however, made this suggestion quite unsuitable, and the final design depicted the queen, Union flags and three representative servicemen (see Figure 3).

A Boer war stamp was also issued in New Zealand (see Figure 4). It was designed by James Nairn, and the postmaster general's official description usefully articulates the multiple messages which the artefact was meant to convey:

Mr Nairn's design for the $1 \frac{1}{2} \mathrm{~d}$. stamp is intended to symbolise the prompt response of New Zealand to the call of the Empire for troops. The New Zealand flag is prominently displayed, and on the left-hand upper corner the value is shown against a background of clematis. On the left-hand side New Zealand flax rises from before the officer standing ready to draw his sword, and in a corresponding position on the right some sprigs of nikau are shown with a tree-fern in the background and a dismounted trooper in front. The wreath near the bottom represents the karaka or New Zealand laurel. Another characteristic of New Zealand is shown by a representation of Maori carving as a background to the words POSTAGE \& REVENUE. ${ }^{50}$

Amazingly, this summary does not include the central part of the stamp, which shows a winged, female figure blowing a bugle, and an army camp with a line of mounted troopers, along with the legend 'The Empire's Call'. Although this plethora of images and words resulted in a hopelessly crowded stamp, what is evident from the design is that the New Zealand aspects of the experience are much more saliently represented than the war itself, which appears as a sort of afterthought, providing some evidence for us that participation in the Boer War might have had a 'nation-building' effect on the territory concerned.

As we have seen, both in these Boer War issues and generally, the monarch's image was by no means a constant in colonial stamp design. There is no compelling evidence to suggest, moreover, that either Victoria or Edward VII was particularly interested in the stamps of Britain or the empire. But from 1910 to 1936 (years during which, by some accounts, the British empire reached its apogee ${ }^{51}$ ) the throne was occupied by 
George V, who had a very special personal interest in philatelic matters. ${ }^{52}$ In his essay on him for the Dictionary of National Biography, Owen Morshead, the librarian at Windsor Castle, recorded that the king's chief 'indoor recreation' was 'his lifelong interest in the postage stamps of the British Empire'. In a 'broadcast to children' after the king's death, Morshead recalled George's opinion that his 'absorbing preoccupation' with stamps had 'saved his life' during the First World War, 'for during such intervals as he could spare from his constant and anxious duties he would obtain complete relaxation poring over some rare issue with the aid of a magnifying glass. ${ }^{53}$ We also know that George $\mathrm{V}$ possessed an encyclopaedic knowledge of ceremonial dress and British imperial iconography in general, and an eagle eye for infractions thereof. ${ }^{54}$ Bearing in mind this combination of factors, a study of British imperial stamp design during George V's reign can not only illuminate perceptions of the empire and its component parts, but it will also touch on an area where the residual power of the British monarch still had some practical impact. ${ }^{55}$

Early in George V's reign the Commonwealth of Australia federal government (which had been inaugurated on 1 January 1901) began planning for the first Australian stamps. Humphry McQueen has argued that the ten-year delay is a further indication that Federation was more a way of binding Australia to Britain than declaring our independence within the Empire. ${ }^{56}$ In 1911 a competition was held and the first prize was won by a design showing George V, flanked by a kangaroo and an emu, beneath the badges of the six Australian states. A Labor government, however, subsequently took office and the new postmaster general did not like the winning entry. He arranged for an alternative design depicting a kangaroo within an outline of the Australian continent which became the basis of the first Australian definitive stamps issued in January 1913 (see Figure. 5). One Labor MP purportedly remarked that he would 'rather lick the backside of a kangaroo than that of King George. ${ }^{57}$ In June 1913, however, the more conservative Liberals returned to power and hastened production of stamps showing George V, surmounted by the imperial crown, together with a kangaroo and an emu, which were issued in December 1913 (see Figure 6). ${ }^{58}$

In contrast to Australia, for its first stamp the newly-created Union of South Africa chose to show George V, the imperial crown, the badges of the four constituent provinces, ${ }^{59}$ and a bilingual inscription in English and Afrikaans. Newfoundland went to town on a 1911 coronation issue which included separate stamps for each member of the immediate royal family (King George, Queen Mary and their six children), as well as the king's mother, Queen Alexandra, and his uncle, the Duke of Connaught. In 1918 Newfoundland, which had pioneered pictorial stamp issues in the 1890s (in part as a revenue-raising exercise), issued a rather sombre series marking the dominion's service in the First World War. The idea was first mooted in late 1917, quickly approved by the executive council, and designs were finalised by the spring of $1918 .^{60}$ The stamps showed the head of a caribou (after the badge of the Newfoundland Regiment). One requirement was to have a distinctive Newfoundland iconography, especially vis-à-vis Canada. 'It is felt', wrote the postmaster general, 'that as Canada has the Maple Leaf for its emblem so Newfoundland should emphasize the Caribou as its 
own peculiar possession. ${ }^{\prime 61}$ Twelve values were issued (in January 1919), eight for the army, bearing the words 'Trail of the Caribou' and the name of a different action (Cambrai, Suvla Bay, Beaumont Hamel and so on), and four for the navy, with 'Royal Naval Reserve' and the inscription 'Ubique' (everywhere). Careful thought was given to the details of the issue: 'the great loss which we sustained on July 1st, 1916 suggests that the 4 cent stamp, which is in mourning colours the Royal Purple, should have Beaumont Hamel for its legend' (see Figure 7). ${ }^{62}$ In just 40 minutes on the first day of the battle of the Somme, the Newfoundland Regiment had suffered over 90 per cent casualties. Of the 752 men who went over the top, only 68 returned unscathed. ${ }^{63}$ While the iconography suited the Newfoundland government, the absence of the king's head on any of the stamps prompted a complaint from the governor, Sir Charles Harris, who thought it improper to have 'an issue of stamps none of which bore the representation of the King'. The Newfoundland government, however, took the line 'that there was no requirement that the postage stamps of the island bear the likeness of the monarch'. ${ }^{64}$

New Zealand also produced a First World War series of stamps, though here the emphasis was more on victory than armed service. The New Zealand postmaster general at the time, Sir Joseph Ward (a former prime minister), was in London in the spring of 1919 and he supervised the design and production of the stamps. Styled a 'Victory Issue', the aim, nevertheless, was 'to commemorate the declaration of peace'. Rather reinforcing the image of New Zealand as the 'most loyal dominion', Ward specifically insisted that 'the design should be imperial in character with a most modest indication of the country of origin'. ${ }^{65}$ So it was. Of the six stamps, just one was unambiguously of New Zealand and showed a portrait of a Maori warrior (see Figure 8). The other five, although they included a little local colour - New Zealand ferns and some Maori-style detailing - principally featured generic icons, such as imperial lions, laurels and allegorical figures of Peace. King George appeared only on the highest-value shilling stamp. That the intention behind the stamps was not just patriotic and celebratory is confirmed by the fact that the stamps were available to dealers in London two months before the official New Zealand launch in January 1920, prompting a bitter complaint from the Christchurch Philatelic Society, which excoriated as 'degrading' the 'haste to make money out of an issue that is intended to celebrate New Zealand's share in the Allies' Victory and to commemorate the sacrifices of its sons. ${ }^{66}$

A clutch of 'Victory' issues from British colonies in the Caribbean region also appears to have been inspired by revenue-raising potential. In May and June 1919 the Bahamas and Barbados respectively set in motion plans for stamps. ${ }^{67}$ The Bahamas, taking no chances with the accompanying iconography, produced a stamp showing the king's head, the imperial crown, the arms and motto of the colony and the word 'peace' (twice) (see Figure 9). Barbados, by a philatelic yardstick much less loyal or imperial, simply ordered two stock designs from the security printers De La Rue depicting winged figures of Victory, which include only the name of the colony, the stamp value and 'Victory 1919'; no king, no crown, no formal heraldry (see Figure 10). We can infer that these were (at least in part) intended 

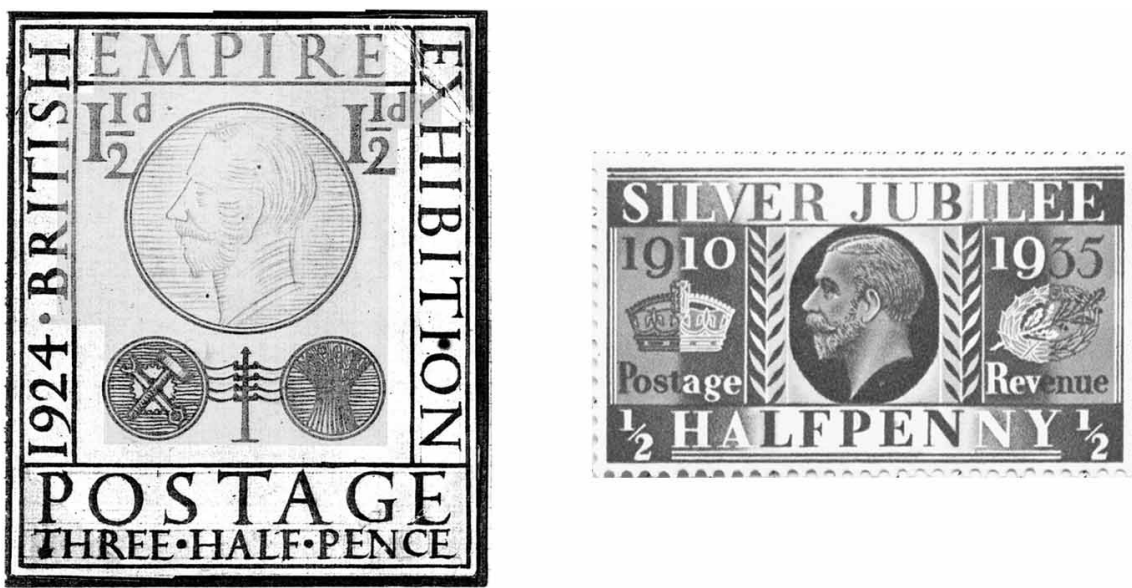

Figures 13-14

for the purely philatelic market by the fact that in October 1919, at the specific suggestion of a commercial stamp dealer, Ewan's Colonial Stamp Market, of Norwood in south-east London, the government of Bermuda expressed interest in producing a victory stamp. ${ }^{68}$ While Bermuda in the end decided to mark the tercentenary of the establishment of representative institutions', both British Honduras and Jamaica issued Great War-related stamps, the former (though not until 1921) closely following the Bahamas design, with the word 'peace' twice repeated on tiny ribbons above the king's head. The Jamaican stamps are the most interesting of all: in 1919 one was issued showing the colony's 'war contingent' departing; in 1921 a second stamp depicted its return (see Figure 11). ${ }^{69}$ In one interpretation these stamps might be said to celebrate the mobilisation of Afro-Caribbeans (of whom over 15,000 served) in support of the imperial war effort. A generous critic might even allow that the depiction of black troops leaving and returning marked their empowerment, and the legitimisation of their participation in the imperial system. But there is a striking contrast between the rather complacent and admiring representation here and the clearly racist treatment which West Indian formations suffered throughout their service. So concerned, indeed, were the authorities (and with good reason) that violence might accompany the repatriation of ex-servicemen that the first main shipload of returning soldiers was met by a warship and a military guard on the wharf, ${ }^{70}$ images not represented on the 1921 stamp.

\section{IV}

What of the 'Mother Country'? The reign of King George V saw the issue of Britain's first-ever commemorative stamp (marking the British Empire Exhibition of $1924-25^{71}$ ) and the first-ever all-empire series (marking the king's silver jubilee in 1935). King George V was regularly consulted about the designs of colonial stamps, ${ }^{72}$ and at home he took a very close interest in all philatelic matters. 
Writing authoritatively in the mid-1930s about the powers of the crown, Arthur Berriedale Keith noted that approval by the crown was required for the designs of all British postage stamps, as well as those of crown colonies and protectorates. ${ }^{73}$ When the possibility of a stamp for the Empire Exhibition was first raised, the king was reported to be 'not very much in favour of stamps of this sort, because the whole idea is un-English and is copied from America'. Yet he also thought that if it is to be done at all, it should be done properly. ${ }^{74}$ A high-powered committee was set up which invited a number of artists to submit designs 'symbolic of the British Empire', and with 'space for a portrait of His Majesty the King. ${ }^{75}$ The proposals of two artists, Harold Nelson and Eric Gill were selected to be submitted to the king. Nelson's design showed a 'British lion' on the background of a rising sun (see Figure 12: this design differs very slightly from the stamp as issued); Gill's wonderfully lettered proposal showed 'mechanical implements, sheaf of corn and telegraph' (see Figure 13). These embodied rather a conservative (if unsentimental) conception of the empire. As Gill explained to the committee, his design represented 'home manufactures in exchange for food', the two 'connected by the symbol of "business", the telegraph'. For himself, he deplored 'elaborate pictorial designs', which would in any case 'often be obliterated by the postmark'. With the increasing reliance on 'picture' stamps, he argued, 'emotion has supplanted good sense. $^{76}$ The king, not noted for his aesthetic sensibilities, disagreed. It was reported that 'the King cannot think Mr Gill's $1 \frac{1}{2} \mathrm{~d}$ design at all attractive', but he 'very much liked' Nelson's lion, which was agreed for the stamp. ${ }^{77}$

Ten years after the British Empire Exhibition, the silver jubilee of George V's accession to the throne provided the opportunity for a great outburst of imperial postal activity, in what might be called the philatelic apotheosis of crown and empire. ${ }^{78}$ Significantly, perhaps, the idea for a general imperial issue first came from the Colonial Office. In January 1934 Gerard Clauson noted that 'we are constantly being pressed by Colonial Govts for permission to make new issues of postage stamps \& have constantly had to refuse them on the ground that no particular reason for the issue (apart from a desire to extract some revenue from the stamp-collecting public) has been shown'. The forthcoming jubilee, however, provided an opportunity for a 'universal' empire issue which 'would be an impressive witness to the unity of the Colonial Empire'. The effect, he thought, 'would of course be greatly enhanced if the U.K., the Dominions and India made similar issues in the approved design at the same time. ${ }^{79}$ This idea was enthusiastically endorsed by Clauson's colleagues, though one of them did not 'see an I. F. S. [Irish Free State] stamp commemorating the occasion! ${ }^{80}$ The Colonial Office then proposed to the Post Office that 'all parts of the Colonial Empire ... should make identical commemorative issues of postage stamps' on 10 May $1935 .{ }^{81}$ The Post Office, however, was very unenthusiastic, and, citing the king's 'laudable dislike of commemorative stamps', replied that it had no plans for any issue. ${ }^{82}$ But when the matter was raised with Buckingham Palace, the king, evidently now reconciled to American philatelic practices, 'expressed himself as warmly favourable to the idea, ${ }^{83}$ and the Post Office swiftly fell in with his wishes. 
A design brief was drawn up which specified the inclusion of the king's head (as designed by Sir Bertram Mackennal for the current British definitive stamps) and made a number of suggestions as to what might be 'appropriate'. These included depictions of royal homes or buildings, 'or scenes of Imperial significance, or perhaps historical scenes such as His Majesty's Coronation in 1911 or events of Imperial importance'. It was further suggested that designs 'symbolical of various national industries, or the development of land, air, sea and electrical communications during the last 25 years' could be proposed. ${ }^{84}$ The response was a large number of pictorial submissions. MacDonald Gill submitted a stamp illustrating 'industry ... suggested by, on the left, coal mining: gear wheel, washery and factories, and on the right by the wireless grid and its masts and similar factories in the background'. John Farleigh proposed 'four of the main methods of modern communication air, sea, rail and telegraph', while Norman Howard 'selected the Armistice ceremony for delineation on one design as being pre-eminently the ceremony linking His Majesty with the great event of his reign and yet being of recurring significance to all the Empire. 85

The Post Office sought advice from Kenneth Clark, the director of the National Gallery, who, strongly deploring pictorial designs, thought none of the submissions was suitable. Eventually a more abstract design, prepared by Barnett Freedman, a relatively unknown book illustrator, was accepted by both Clark and the king. ${ }^{86}$ There were four stamp designs, on each of which appeared the king's head, the imperial crown, and 'Silver Jubilee 1910 1935'. They were individually distinguished by various combinations of laurel, olive and oak leaves which Freedman explained were meant respectively to symbolise 'triumph and reward', 'peace and goodwill' and 'strength and stability' (see Figure 14). ${ }^{87}$

The common colonial design (which was used by 44 different territories) evidently gave rather less trouble, and was much more representationally imperial than the understated, mildly modernist British stamp. Designs were solicited from three security printers, the only guidance given being that the 'designs should bear relation to the King and his reign, and be in a peculiar sense personal to His Majesty'. ${ }^{88}$ Bradbury Wilkinson produced a number of more or less generic royal images concentrating on the king's coronation in Westminster Abbey. De La Rue produced a greater range of subjects, including the Cenotaph in Whitehall, Buckingham Palace and the king between two radio masts, symbolising the modern communications which enabled him, for example, to broadcast an annual Christmas message to the empire. Waterlow and Company put forward a couple of coronation-based designs, as well as one showing the king flanked by a 'native' and a 'settler', while another combined three images of the king: wearing the imperial crown; working at his desk; and sailing his beloved royal yacht Britannia. Waterlow's were also responsible for the design (by staff artist Harold Fleury) which George V eventually selected for use.

'It would seem impossible', wrote Frederick Wall in Gibbons' Stamp Monthly, 'to concentrate the whole story of a mighty empire and the brilliant pageantry of an ages-old kingship within the border of a postage stamp design, but', he claimed, 'it is typical of the art of modern stamp design that it can be done, and it has been 
done for the Colonial Silver Jubilee issue. ${ }^{89}$ The stamp showed King George V, wearing the imperial crown and framed by the collar of the Order of the Garter, superimposed on the royal sceptre, the dove sceptre and the sword of state. In the top left corner was the orb and the middle of the stamp showed a view of Windsor Castle from across the River Thames. Each colony's name appeared in the sky above the castle (see Figure 15).

The Indian silver jubilee stamp was loosely based on the colonial design. In November 1934 the Indian government sought London's approval to issue commemorative stamps 'bearing scenic views of certain Hindu, Mohammedan, Jain and Christian buildings. 90 The secretary of state for India, Sir Samuel Hoare, immediately raised the question of the royal portrait. 'Although there are many Colonial and Dominion stamps which are entirely pictorial', wrote an Indian Office official, 'I believe that no British Indian stamp has ever been issued which did not bear the Sovereign's portrait' (this was true). There was also a concern about displaying religious buildings which recalled a row in 1929 over a proposed airmail stamp design which originally showed a Hindu temple and a Muslim mosque. ${ }^{91}$ London was reassured that the king's head would be included, as was the king himself, who wanted his image to cover 'about a third of the stamp'. Hoare reported that he had spoken personally to the king about the jubilee stamps and that he was 'taking a great personal interest in the various issues in the Empire.92 It was decided that the royal portrait would be surrounded by the collar of the Order of the Star of India and that the images shown would be selected 'so as to include Christian, Muhammadan, Hindu, Sikh and Jain buildings. ${ }^{93}$

King George V's jubilee was marked with an imperial postal celebration in which the dominions combined as never before. The actual image of the king which it was proposed to use caused some difficulties for New Zealand, which decided to show both King George and Queen Mary within 'a border identifying New Zealand with the issue.94 The initial design showed the king in a lounge suit, which would have been the first time a male British monarch appeared other than as a medallion, in military uniform or ceremonial robes. When the design went to Buckingham Palace for approval, the proposal was struck out as 'too undignified' and a photograph of the king in the uniform of the Welsh Guards substituted (see Figure 16). ${ }^{95}$ Canada also issued a stamp showing king and queen together, as well as stamps with other members of the royal family, Windsor Castle and the royal yacht Britannia. Each stamp was decorated with maple leaves. For a self-consciously independent-minded dominion, the principal stamp was rather a rococo effort, unambiguously imperial and regal with the king and queen in coronation robes and wearing crowns (see Figure 17), a sharp contrast to the more prosaic original New Zealand design, which rather belied the 'dutiful daughter' image of that dominion. ${ }^{96}$ In fact, it was Canada which first portrayed the monarch in 'civvies' (as it were) in a 1937 stamp showing King George VI. This was a definite step away from mystic medieval notions of monarchy and towards a new and more prosaic conception of the head of state as a type of chief executive.

The Australian stamp had a particular significance in that it came out shortly after a stamp to mark the twentieth anniversary of the disastrous Gallipoli campaign, where 
the Australian and New Zealand Army Corps - 'Anzac' - were first blooded in the Great War. The Anzac experience has become part of the Australian nation's 'creation myth', and yet in 1935 the image chosen to mark the anniversary was the Cenotaph in London, a clearly British imperial monument. The only specifically Australian iconography was confined to a couple of sprigs of wattle in the bottom corners of the stamp. The design was suggested by the veterans' organisation, the Returned Soldiers' Association, to embody 'Remembrance', the Cenotaph 'honouring the memory of the Empire's fallen' (see Figure 18). ${ }^{97}$ This anniversary, however, was held to be less important than the royal silver jubilee and the Anzac stamp was limited to one print run so as not to interfere with the silver jubilee issue. ${ }^{98}$ While the Anzac stamp design seemed to embody a continued deferral to the imperial metropolis, it can be argued that the silver jubilee stamp further demonstrated Australia's subordinate status, for the image chosen (and personally authorised by King George $^{99}$ ) showed the king mounted on a horse called 'Anzac', which had been a gift from the Australian government (see Figure 19). Neither the name of the horse, nor its provenance, is indicated on the stamp, yet the implicit message is suggestive. Although the metaphor should not be stretched too far, while horses have their own individual character, they also have to be 'broken in' before they can be ridden, and, vis-à-vis horse and rider, it is generally quite clear who is in charge. On the other hand, the actual image of the king on the British silver jubilee stamp was drawn by an Australian sculptor, Sir Bertram Mackennal, though one long-resident in England. So perhaps the Australians have the last laugh after all.

\section{V}

In a typically punchy essay in 1972 Ged Martin raised the question of whether there had, in fact, ever been any such thing as 'the British empire', that, far from there having been any coherent world system, all that existed was a series of bilateral relationships between Great Britain and a disparate collection of overseas territories. ${ }^{100}$ But perhaps we can find an empire, of sorts, in the philatelic legacy, and, moreover, one which, ironically, was later-flowering than one might have supposed. There was less consistency in the use of Queen Victoria's image on colonial stamps than that of George V. By his reign the monarch's image was represented across the empire not merely in dominions and crown colonies, but also protectorates and mandates. In 1920, for example, the official design brief for the stamps for Tanganyika, newlyacquired under a League of Nations mandate, laid down that they 'should not show the King's head or any other symbol suggesting sovereignty over the territory.' ${ }^{101}$ In 1927 there was a row when stamps were issued for the 'Mandated Territory of Tanganyika' bearing King George V's head, and in 1935 Tanganyika (albeit now joined with Kenya and Uganda in a single postal administration) was but one of the 44 territories issuing the uniform issue (king, crown and all) for the silver jubilee.

It is remarkable that the first co-ordinated all-empire issue of stamps should not happen until as late as 1935. The silver jubilee issue, moreover, was the first of only six similar imperial stamp issues over the next 18 years, culminating with the 

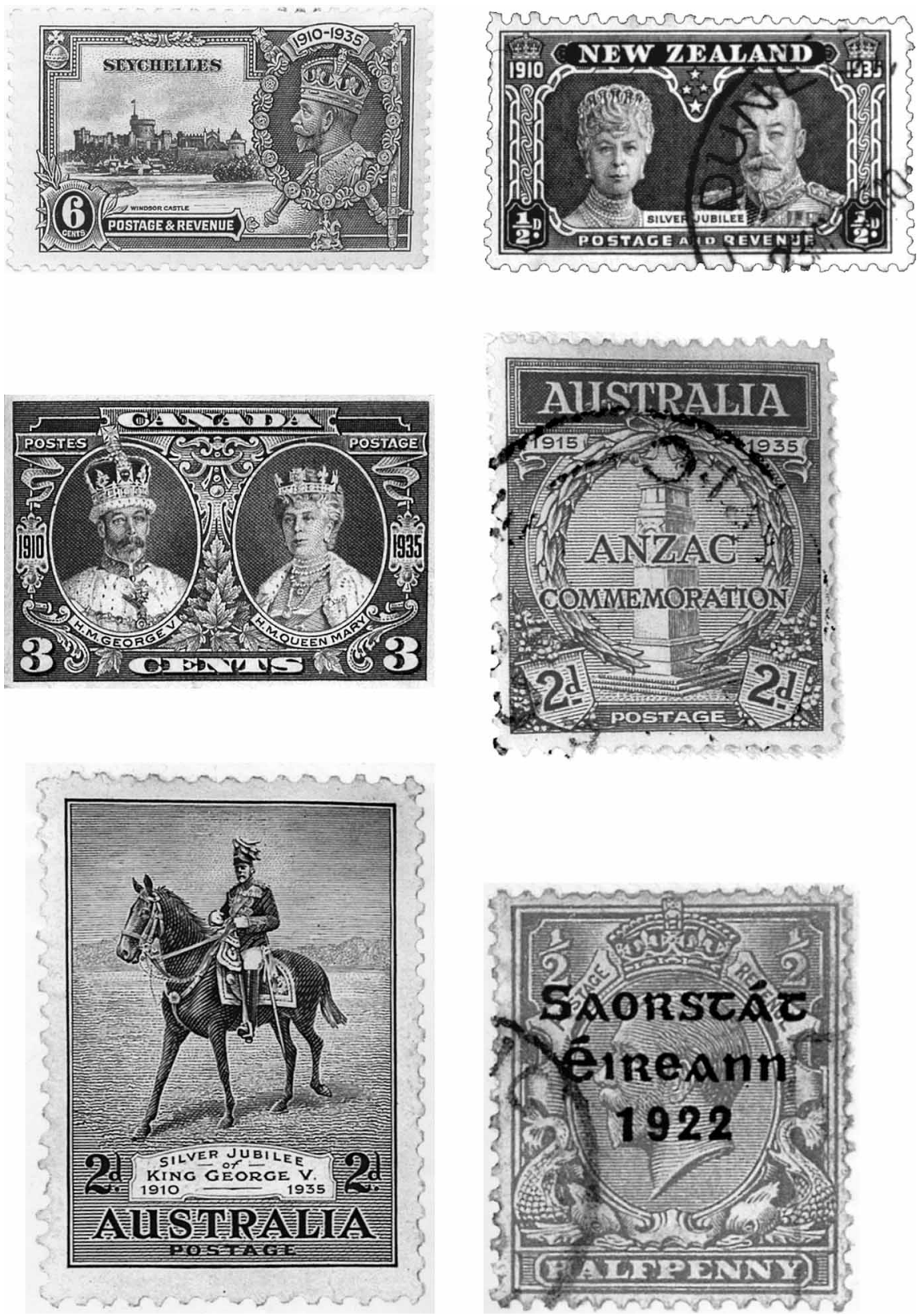

Figures 15-20

coronation of Queen Elizabeth II in 1953. Four of these issues - the 1935 silver jubilee, the coronations of George VI and Elizabeth II, and the royal silver wedding of George VI and Queen Elizabeth in 1948 - were royal occasions, illustrating how the British royal family were a central and iconic component of the imperial world system, 
representing a unified and central point of contact and confirming Berriedale Keith's assertion that 'the most important and vital link of Empire is in the person of the king and the Crown. ${ }^{102}$ But these all-empire issues also celebrated an imperial (and by 1953 Commonwealth) unity which may no longer have existed. Yet the continued application of a distinctive imperial and commonwealth postage rate meant that the apparently spurious unity expressed by these stamp issues had, in fact, some practical (and beneficial) utility.

If the persistence of the late-flowering British empire was reinforced by the crown and the royal image as reproduced on such things as postage stamps, coins and banknotes, the converse is also true. With independence comes national re-branding, and among the first actions of any newly independent state is the production of national stamps, notes and coins. ${ }^{103}$ One example of this counter-narrative is found in the defacing of the royal philatelic image. For inhabitants of the Irish Free State in midFebruary 1922 one of the first unambiguous indicators of constitutional change was to be found at every post office in the country, where the image of King George on British stamps was in February 1922 defaced with 'Rialtas Sealadac na hÉireann 1922' (Provisional Government of Ireland), ${ }^{104}$ and in December with 'Saorstát Éireann' (Irish Free State) (see Figure 20). Thus (as they say in philatelic circles) was the old order cancelled.

\section{Acknowledgement}

Versions of this article were given to the Exhibiting Empire Conference (National Maritime Museum, October 1999), and seminars at London, Oxford, Swansea, UWE Bristol, and the Cultural Heritage Centre for Asia and the Pacific at Deakin University in Melbourne. I also wish to thank Joan Beaumont, David Beech, Andrew Cook, Kent Fedorowich, John Gooch, Ronald Hyam, Ken Inglis, Joanna Lewis, Chris Lloyd, Rory Rapple, Michael Sefi, Gavin Souter, Andrew Thompson, Jock Phillips and, above all, Sally Visick for help and advice. The reproduction as illustrations of unpublished material is by courtesy of the following: Queensland Museum, Brisbane (Figures 2-3) and the British Postal Museum and Archive (Figures 12-13).

\section{Notes}

[1] Seanad Éireann Official Report, Vol.6, 3 March 1926, col.501.

[2] Pevsner, 'Style in stamps', 464.

[3] Similar claims can, of course, be made for paper money. See, for example, Gilbert, "'Ornamenting the facade of hell"', 57-80; and Blaazer, 'Reading the Notes', 39-53.

[4] Scott, European Stamp Design, 7 (emphasis in original).

[5] McQueen, 'The Australian Stamp', 81.

[6] Reid, 'The Symbolism of Postage Stamps', 223-49. This article is mostly devoted to an exploration of stamps of the Ottoman Empire and its successor states. The only British academic interest in philately I can discover is a University of Sussex 'Philatelic Unit' which existed in the 1970s. For further information contact Special Collections at the University of Sussex Library. In the United Kingdom, nevertheless, the scholarly study of philatelic 
matters is supported by the Royal Philatelic Society London, the British Library Philatelic Collections, and the British Postal Museum and Archive.

[7] Hobsbawm, The Age of Capital, 48-68. But see Hobsbawm, 'Mass-Producing Tradition', 276, 281 , on the use of historical themes on stamps.

[8] Reid, 'The Symbolism of the Postage Stamp', 225. In The Birth of the Modern World, Bayly is no better. While acknowledging that the nineteenth century was 'the age of global communication', and giving credit for this to the electric telegraph, the railway, the steamship 'and, later, the telephone' (19-20), no mention is made of postal services. He observes, too, the growth of newspapers as a means of mass communication (211), but without remarking on the postal privilege which they enjoyed, and which greatly facilitated their distribution at home and abroad. In 1895, for example, printed papers could be sent overseas at a rate of a halfpenny per two ounces weight (information from Whitaker's Almanack).

[9] 20,973,535 telegrams; 1,008,392,100 letters; 87,116,300 post cards; $158,666,600$ printed books and circulars; 121,049,400 newspapers (26th Report of the Postmaster General on the Post Office [C.2670], H.C. 1880, xix, pp.26, 27, 34). The figure for telegrams includes messages to foreign as well as domestic destinations; those for postal items only apply to domestic UK mail.

[10] 2,804 million letters; 1,122 million newspapers and printed papers; 831 million post cards. Figures extracted from Board of Trade, Statistical Abstract for the United Kingdom, 1906 to 1920 (HMSO, 1922 Cmd. 1774), 314-16.

[11] E. A. Benians, 'Imperial Finance, Trade and Communications, 1870-1895', 200; and Graham, 'Imperial Finance, Trade and Communications, 1895-1914', 473. In a footnote, however, Benians added that in 1890 Britain agreed a uniform colonial and Indian postage rate of two pence halfpenny per half ounce. Graham's 'sixpence-a-word cables' was a pipe dream. Telegram rates to Canada (the cheapest dominion destination) were $3 \mathrm{~s} .8 \mathrm{~d}$. a word in the 1890s, 1s. in the 1920s and $7 d$. in the 1930s (information from Whitaker's Almanack).

[12] E. H. H. Green, 'The Political Economy of Empire, 1880-1914', 347.

[13] Ronald Hyam, Britain's Imperial Century, 108 (emphasis in original). Hyam does, however, mention imperial mail in 'The British Empire in the Edwardian Era', 49.

[14] Porter, The Lion's Share, 41.

[15] Lloyd, The British Empire, 225.

[16] Cannadine, Ornamentalism, 103. Cannadine makes some remarks about British commemorative stamps in his chapter, 'The Context, Performance and Meaning of Ritual', 155.

[17] And scholars too, as John Iliffe has testified to the author.

[18] Morris, Pax Britannica, 58-60.

[19] In Australia, for example in 1912 there were 77,663 government railway employees; 29,914 post office employees (as well as 4,458 mail contractors); and 19,237 teachers in state schools: Official Year Book of the Commonwealth of Australia, No.7, 1914 (Melbourne, 1914), 639, 678, 772.

[20] Post Office archives are a valuable and much-underused resource by general historians. For some comments on the British archives see Jeffery, 'Letters, Bombs and Local History', 207-20. Gary Magee (University of Melbourne) and Andrew S. Thompson (University of Leeds) have been investigating remittance flows in the 'British world' using information from the Post Office archives.

[21] An analogy may be found in the state identifiers in e-mail addresses. In the country (the United States) which pioneered this form of communication they do not carry '.usa'.

[22] See the discussions of cabinet and monarchy in Bagehot, The English Constitution, 59-120, and the lucid introduction to this edition by Richard Crossman, itself containing some revealing remarks regarding the contemporaneous 'English' constitution.

[23] See, generally, Hobsbawm and Ranger, The Invention of Tradition, but especially the introduction (by Hobsbawm) and the chapter by David Cannadine, 1-14 and 101-64. 
[24] Quoted in Robinson, Carrying British Mails Overseas, 252.

[25] For Mulready, see Heleniak, William Mulready.

[26] Unless otherwise noted, the details concerning British and Commonwealth stamps are based on the information and images in Stanley Gibbons Postage Stamp Catalogue Part One: British Commonwealth 1968. There is a useful discussion of the monarch's head on British stamps in Scott, European Stamp Design, 17-19.

[27] The apparent paradox in the differing treatment of the monarch's image on British stamps and coins (which is not confined to Queen Victoria) would be worth exploring. On stamps, despite their high turnover, the monarch remains young; on coins, with their rather longer 'shelf life', she ages. In contrast to Britain, however, Victoria ages on some colonial stamps, such as Canada and India.

[28] With one exception: the $5 d$. stamp of 1887 also included the royal coat of arms.

[29] There were two exceptions: the King George V high value stamps (2s. $6 d$., 5s., 10s. and $\mathfrak{E} 1$ ) of 1913-36 (but which do show Britannia, with trident, in a horse-drawn chariot); and the $2 \frac{1}{2} d$. Universal Postal Union Congress stamp of 1929.

[30] Cell, British Colonial Administration in the Mid-Nineteenth Century, 152.

[31] Crisp, Australian National Government, 111.

[32] Both men personally claimed credit for the imperial penny post in their Who's Who entries.

[33] See, for example, his interventions in the House of Commons, 10 and 22 Sept. 1886, Hansard, 309 H.C. Deb. 3d ser., col.14, 1260-61; and his daughter's account of his campaign in Porter, The Life and Letters of Sir John Henniker Heaton, 174-82.

[34] Heaton, 'Imperial Postal Services', 312.

[35] See Ottawa-London correspondence, Sept.-Dec. 1897, Canadian Post Office records, National Archives of Canada (NAC), RG3 vol.2749, file 6.

[36] J. S. Coulter (deputy postmaster general, Ottawa) to Sir Spencer Walpole (secretary to the Post Office, London), 20 Dec. 1897, ibid.

[37] For a good account of the Imperial Penny Postage campaign, concentrating on Canada and William Mulock, see Pike, 'National Interest and Imperial Yearnings', 22-48.

[38] A uniform empire (and later commonwealth) letter rate, significantly lower than that for foreign destinations, survived into the early 1970s.

[39] The Times, 24 Dec. 1898.

[40] 'Letters, post cards and other articles' despatched from the UK to British colonies, shown in pounds weight: 431,800 (1897-98); 989,000 (1903-04) (Heaton, 'Imperial Postal Services', 314).

[41] With the exception of the Bechuanaland Protectorate, Rhodesia and some distant islands, to which the charge was two pence halfpenny.

[42] Whitaker's Almanack 1906, 466, 469.

[43] Minutes of conference on postage within the British empire, 12 July 1898, NAC RG3 vol.2749, file 6.

[44] 'We hold a vaster Empire than has been!/Nigh half the race of man is subject to our Queen,/ Nigh half the wide, wide earth is ours in fee,/And where her rule comes all are free.' Notes on the 1898 map stamp (ibid., file 4).

[45] This dramatically enlarges features the closer they are to the poles, so that Canada (3.8 million square miles in area) appears larger than the entire African continent (11.7 million square miles).

[46] See for example, Mansergh, The Commonwealth Experience.

[47] Berger, The Sense of Power, 259.

[48] See Jeffery, 'Kruger's Farmers, Strathcona's Horse, Sir George Clarke's Camels and the Kaiser's Battleships', 188-202.

[49] In the L'Strange collection of stamps, Queensland Museum, Brisbane. I am most grateful to Chris Lloyd for showing me this material. 
[50] Collins and Fathers, eds., The Postage Stamps of New Zealand, 194. This exceptionally valuable work draws extensively on official Post \& Telegraph Department documentation, which has not survived in the New Zealand National Archives. A catastrophic fire in 1961 destroyed the departmental records, a warning perhaps against housing government departments in wooden office-buildings.

[51] See Jeffery, The British Army and the Crisis of Empire, p.1, line 1.

[52] Rose, King George V, 40-42; Wilson, The Royal Philatelic Collection, 5-44.

[53] The Times, Hail and Farewell, 158.

[54] Rose, King George V, 185-86, 305-06.

[55] Hardie, The Political Influence of the British Monarchy, is, however, curiously silent on this application of the royal prerogative.

[56] McQueen, 'The Australian Stamp', 81.

[57] See Best, Humanity in Warfare, 338 n.23. The wider context of this debate may be followed in Gavin Souter's 'history of sentiment', Lion and Kangaroo; and, for other visualisations of Australia, see McDonald, Federation.

[58] Both designs survived for some years, but by the mid-1920s the king's head had supplanted the kangaroo for lower-value stamps. The quest for the ideal Australian philatelic icon continues, see Humphries, 'The Gladdy Stamp', 126-27.

[59] Cape of Good Hope, Natal, Orange Free State and Transvaal.

[60] See correspondence between the colonial secretary and the postmaster general, Dec. 1917Apr. 1918, Public Archives of Newfoundland (PAN), GN 2/5/356.

[61] Note by J. A, Robinson, n.d. (c. March 1918), British Postal Museum and Archive (London) (BPMA), De La Rue Newfoundland correspondence (microfilm), vol.1, fol.98.

[62] Ibid.

[63] Middlebrook, The First Day on the Somme, 189.

[64] Deputy colonial secretary to postmaster general, 4 Dec. 1918, PAN, GN 2/5/356; Boggs, The Postage Stamps and Postal History of Newfoundland, 93.

[65] This account is drawn from Collins and Fathers, eds., The Postage Stamps of New Zealand, $380-82$.

[66] Ibid., 381.

[67] See Crown Agents correspondence with Bahamas, 24 May 1919, and Barbados, July-Aug. 1919, BPMA, De La Rue-Crown Agents correspondence (microfilm), vol.68, fols.38 and 62.

[68] Colonial secretary, Bermuda, to Crown Agents, 29 Oct. 1919, ibid., fol.194.

[69] For the West Indian experience, see Howe, Race, War and Nationalism; Smith, Jamaican Volunteers in the First World War; and Joseph, 'The British West Indies Regiment 1914-1918', 94-124.

[70] Howe, Race, War and Nationalism, 191-92.

[71] For a brief account of the exhibition in the context of changing British-imperial relationships, see Keith Jeffery, 'British Isles/British Empire', 13-41.

[72] See Crown Agents to De La Rue \& Co., 2 Dec, 1916, and Wilfrid M. Wigley (acting administrator, St Kitts) to Crown Agents, 22 Sept. 1919, both noting royal approval for proposed stamps, BPMA, De La Rue-Crown Agents correspondence (microfilm), vol.68, fols.193 and 150 .

[73] Berriedale Keith, The King and the Imperial Crown, 358. He also added inaccurately that 'no longer is any attempt made to apply this rule to the Dominions'. As is noted below, royal approval was asserted for silver jubilee issues.

[74] Sir Warren Fisher (permanent secretary to the Treasury) to Sir Evelyn Murray (secretary to the Post Office), 10 Dec. 1923, quoting a letter from Sir Frederick Ponsonby (treasurer to the King), BPMA, POST 33/2205A, M13984/35.

[75] 'Instructions to artists for preparation of designs for stamps', 16 Jan. 1924, ibid., M1432/28. 
[76] Minutes of Stamp Design Committee, 19 Feb. 1924 (ibid.), and Note by Eric Gill, 31 Jan. 1924, BPMA, POST 33/4840 M13984/35. Gill, ironically, had reviled both industry and monarchy, but he did not let his beliefs stand in the way of a commission (MacCarthy, Eric Gill, 271).

[77] Lord Stamfordham (private secretary to the King) to Murray, 28 Feb. 1924, BPMA, POST 33/ $4840 \mathrm{M} 13984 / 35$.

[78] Not just stamps, but coins and medals too: at the silver jubilee celebrations on 6 May 1935 at Kakamega, western Kenya, the district commissioner observed that 'King George was present, even to the meanest of his subjects, in his image on their coins, on the medals of their chiefs' (John Lonsdale, 'State and Peasantry in Colonial Africa', 113).

[79] Minute by G. L. M. Clauson, 30 Jan. 1934, The National Archives (TNA, formerly the Public Record Office), CO 323/1274/5; copy in British Library Philatelic Collections (BLPC) Crown Agents file G/1288/23.

[80] Minute by R. V. Vernon, 30 Jan. 1934, ibid. Vernon had been assistant secretary to the Irish Convention in 1917-18.

[81] F. G. Lee (Colonial Office) to A. Napier (Post Office), 14 Feb. 1934, BPMA, POST 33/4646; draft copy in CO 323/1274/5.

[82] Minute to postmaster general, 16 Feb. 1934, BPMA, POST 33/4646, and postmaster general to colonial secretary, 28 Feb. 1934, CO 323/1274/5. Only one commemorative issue, for the 1929 Postal Union Congress, had been produced in Britain since the Empire Exhibition.

[83] Memo by Sir Donald Banks, 8 June 1934, BPMA, POST 33/4646.

[84] Memo for artists, 30 July 1934, ibid.

[85] Submissions from Gill, Farleigh \& Howard, 15 Sept., 8 and 15 Oct. 1934, ibid. MacDonald Gill was Eric Gill's eldest brother.

[86] Minutes by A. R. Kidner, 21 Sept., 25 Oct. and 22 Nov. 1934, ibid.

[87] Bates, '1935 Silver Jubilee', 15.

[88] Colonial Office to Crown Agents, 9 Aug. 1934, BLPC Crown Agents file G/1288/23; draft copy in CO 323/1274/5. See also correspondence in Crown Agents Commemorative Issue file, Aug. 1934-Dec. 1935, BPMA, microfilm reel no.78. The printers concerned were Bradbury Wilkinson, Waterlow and De La Rue. The descriptions which follow of the proposed designs are taken from material in the Royal Philatelic Collection.

[89] Frederick Wall, 'The Silver Jubilee Stamps', 144-45 (emphasis in original).

[90] Government of India Department of Industries and Labour to secretary of state for India, 7 Nov. 1934, British Library, India Office Records, L/F/7/2132, fol.50.

[91] See papers in 'Introduction of Air Mail Postage Stamps' file, ibid., L/F/7/2129, fols.1-86.

[92] Hoare to Lord Willingdon (viceroy), 23 Nov. 1934, ibid., L/F/7/2132, fol.38.

[93] Willingdon to Hoare, 9 Dec. 1934, ibid., fol.23.

[94] Memo from New Zealand Prime Minister's Office, 8 Nov. 1934, BPMA, POST 52/543.

[95] Undated minute, ibid. The artist's design and the design as used are illustrated in Collins and Fathers, eds., The Postal Stamps of New Zealand, 390.

[96] The phrase is F. L. W. Wood's; see Ross, 'Reluctant Dominion or Dutiful Daughter?', 28-43.

[97] Postmaster general draft letter to the press, March 1935, Australian Archives, Victorian Office (Melbourne), MP341/1.

[98] For the Anzac stamp, see Cochrane, Simpson and the Donkey, 224-5; and the stimulating remarks in McQueen, 'The Australian Stamp', 86-87.

[99] High commissioner, London, to prime minister, 1 Nov. 1934, Australian Archives (Melbourne), MP341/1 1935/6377.

[100] Martin, 'Was There a British Empire?', 562-69.

[101] 4 Aug 1920, Crown Agents to De La Rue, BPMA, De La Rue-Crown Agents correspondence (microfilm), vol.70, fol.99.

[102] Berriedale Keith, The King and the Imperial Crown, 452. 
[103] For a stimulating exploration of the Irish experience, see Morris, 'Our Own Devices'; and, for the postal aspects, Dulin, Ireland's Transition.

[104] In the House of Commons, Sir Charles Oman complained about the new Irish government defacing stamps 'by blocking out the head of His Majesty by an inscription in Erse'. He also asserted (inaccurately) that the word which was 'believed to mean "Provisional" [seala$d a c]$ and which is stamped across His Majesty's head is by a mistake in the dictionary a word which really means "preposterous"'. The postmaster general declined 'to enter into a dispute with my hon. Friend on this point' (Hansard, 7 Mar. 1922, 151 H.C. Deb. 5th ser., col.1058). Oman (who may have been wilfully misled) was confusing sealadac with seafoideac, which does mean 'preposterous' or 'ludicrous'.

\section{References}

Bagehot, Walter. The English Constitution. Fontana edn. London, [1867] 1963.

Bates, Simon. '1935 Silver Jubilee' (Special Stamp History No.3). National Postal Museum Review of 1992.

Bayly, C. A. The Birth of the Modern World, 1780-1914. Oxford: Blackwell, 2004.

Benians, E. A. 'Imperial Finance, Trade and Communications, 1870-1895'. In The Cambridge History of the British Empire, Vol. III, The Empire-Commonwealth 1870-1919, edited by E. A. Benians et al. Cambridge: Cambridge University Press, 1959.

Berger, Carl. The Sense of Power: Studies in the Ideas of Canadian Imperialism, 1867-1914. Toronto: University of Toronto Press, 1970.

Berriedale Keith, A. The King and the Imperial Crown: The Powers and Duties of His Majesty. London: Longmans, 1936.

Best, Geoffrey. Humanity in Warfare. Methuen pbk edn. London, 1983.

Blaazer, David. 'Reading the Notes: Thoughts on the Meanings of British Paper Money'. Humanities Research 1 (1999): 39-53.

Boggs, Winthrop S. The Postage Stamps and Postal History of Newfoundland. Lawrence, MA: Quarterman, 1975.

Cannadine, David. 'The Context, Performance and Meaning of Ritual: The British Monarchy and the "Invention of Tradition", c.1820-1977'. In The Invention of Tradition, edited by Eric Hobsbawm and Terence Ranger. Canto edn. Cambridge, 1983.

. Ornamentalism: How the British saw their Empire. Penguin edn. London, 2002.

Cell, John W. British Colonial Administration in the Mid-Nineteenth Century: The Policy-Making Process. New Haven: Yale University Press, 1970.

Cochrane, Peter. Simpson and the Donkey: The Making of a Legend. Burwood, Vic.: Melbourne University Press, 1992.

Collins, R. J. G. and H. T. M. Fathers, eds. The Postage Stamps of New Zealand. Wellington: Philaletic Society of New Zealand, n.d. [1938].

Crisp, L. F. Australian National Government. Croydon, Vic.: Longmans, 1965.

Dulin, C. I. Ireland's Transition: The Postal History of the Transitional Period 1922-1925. Dublin: MacDonnell Whyte, 1992.

Gilbert, Emily. "Ornamenting the facade of hell”: Iconographies of 19th-Century Canadian Paper Money'. Environment and Planning D: Society and Space 16 (1998): 57-80.

Graham, G. S. 'Imperial Finance, Trade and Communications, 1895-1914'. In The Cambridge History of the British Empire, Vol.III, The Empire-Commonwealth 1870-1919, edited by E. A. Benians et al. Cambridge: Cambridge University Press, 1959.

Green, E. H. H. 'The Political Economy of Empire, 1880-1914'. In The Oxford History of the British Empire, Vol.III, The Nineteenth Century, edited by Andrew Porter. Oxford: Oxford University Press, 1999.

Hardie, Frank. The Political Influence of the British Monarchy, 1868-1952. London: Batsford, 1970. 
Heaton, J. Henniker. 'Imperial Postal Services'. In The Empire and the Century, edited by C. S. Goldman. London: John Murray, 1905.

Heleniak, Kathryn Moore. William Mulready. New Haven: Yale University Press, 1980.

Hobsbawm, Eric. The Age of Capital, 1848-1875. London: Weidenfeld \& Nicolson, 1975.

- 'Mass-Producing Tradition: Europe, 1870-1914'. In The Invention of Tradition, edited by Eric Hobsbawm and Terence Ranger. Canto edn. Cambridge: Cambridge University Press, 1983.

Howe, Glenford. Race, War and Nationalism: A Social History of West Indians in the First World War. Oxford: James Currey, 2002.

Humphries, Barry and Other Creatures. 'The Gladdy Stamp'. In Neglected Poems. North Ryde, NSW: Angus and Robertson, 1991.

Hyam, Ronald. Britain's Imperial Century. London: Batsford, 1976.

. 'The British Empire in the Edwardian Era'. In The Oxford History of the British Empire, Vol.IV, The Twentieth Century, edited by Judith M. Brown and Wm Roger Louis. Oxford: Oxford University Press, 1999.

Jeffery, Keith. The British Army and the Crisis of Empire. Manchester: Manchester University Press, 1984.

. 'Kruger's Farmers, Strathcona's Horse, Sir George Clarke's Camels and the Kaiser's Battleships: The Impact of the South African War on Imperial Defence'. In The South African War Reappraised, edited by Donal Lowry. Manchester: Manchester University Press, 2000.

. 'British Isles/British Empire: Dual Mandate/Dual Identity'. In Britain 1900-1950, edited by Keith Robbins. Oxford, 2002.

'Letters, Bombs and Local History'. Local Historian 33, no.4 (Nov. 2003): 207-20.

Joseph, C. L. 'The British West Indies Regiment 1914-1918'. Journal of Caribbean History 2 (May 1971): $94-124$.

Lloyd, T. O. The British Empire, 1558-1983. Oxford: Oxford University Press, 1984.

Lonsdale, John. 'State and Peasantry in Colonial Africa'. In People's History and Socialist Theory, edited by Raphael Samuel. London: Routledge \& Kegan Paul, 1981.

MacCarthy, Fiona. Eric Gill. London: Faber, 1989.

McDonald, John. Federation: Australian Art and Society 1901-2001. Canberra: National Gallery of Australia, 2000.

McQueen, Humphrey. 'The Australian Stamp: Image, Design and Ideology'. Arena (North Carlton, Victoria) 84 (Spring 1988): 78-96.

Mansergh, Nicholas. The Commonwealth Experience. London: Weidenfeld \& Nicolson, 1969.

Martin, Ged. 'Was There a British Empire?'. Historical Journal 15, no.3 (1972): 562-69.

Middlebrook, Martin. The First Day on the Somme. Penguin edn. London, 2001.

Morris, Ewan. 'Our Own Devices': National Symbols and Political Conflict in Twentieth-Century Ireland. Dublin: Irish Academic Press, 2004.

Morris, James. Pax Britannica: The Climax of an Empire. Penguin edn. Harmondsworth, 1979.

Pevsner, Nikolaus. 'Style in Stamps: A Century of Postal Design'. Country Life, 4 May 1940.

Pike, Robert M. 'National Interest and Imperial Yearnings: Empire Communications and Canada's Role in Establishing the Imperial Penny Post'. Journal of Imperial and Commonwealth History 26, no.1 (Jan. 1998): 22-48.

Porter, Mrs Adrian. The Life and Letters of Sir John Henniker Heaton. London: John Lane, 1916.

Porter, Bernard. The Lion's Share: A Short History of British Imperialism, 1850-1970. London: Longman, 1975.

Reid, Donald M. 'The Symbolism of Postage Stamps: A Source for the Historian'. Journal of Contemporary History 19 (1984): 223-49.

Robinson, Howard. Carrying British Mails Overseas. London: George Allen and Unwin, 1964.

Rose, Kenneth. King George V. London: Weidenfeld \& Nicolson, 1983. 


\section{K. Jeffery}

Ross, Angus. 'Reluctant Dominion or Dutiful Daughter? New Zealand and the Commonwealth in the Inter-War Years'. Journal of Commonwealth Political Studies 10, no.1 (March 1972): 28-43.

Scott, David. European Stamp Design: A Semiotic Approach to Designing Messages. London: Academy Editions, 1995.

Smith, Richard. Jamaican Volunteers in the First World War: Race, Masculinity and the Development of National Consciousness. Manchester: Manchester University Press, 2004.

Souter, Gavin. Lion and Kangaroo: The Initiation of Australia, 1901-1919. Sydney: Collins, 1976.

Stanley Gibbons Postage Stamp Catalogue Part One: British Commonwealth 1968. London, 1967.

Times, The. Hail and Farewell: The Passing of King George V. London: The Times, 1936.

Wall, Frederick. 'The Silver Jubilee Stamps'. Gibbons' Stamp Monthly (May 1935).

Wilson, John. The Royal Philatelic Collection. London: Dropmore Press, 1952. 